\title{
EFFECTS OF WATER QUALITY, pH AND STATE OF THE MEDIUM ON GROWTH AND DEVELOPMENT OF COCONUT EMBRYOS IN VITRO
}

\author{
By
}

\author{
M.B.B. Areza, E.P. Rillo, C.A. Cueto, \\ A.W. Ebert \& O.D. Orense ${ }^{1}$
}

\begin{abstract}
The effects of the quality qfwater, $\mathrm{pH}$ and state qf the medium on growth and development of coconut embryos in vitro were evaluated. Germination of embryos in Y3 liquid medium was not affected by neither wau ,r quality nor $\mathrm{pH}$ adjustment. These suggest that tap water could replace glass distilled water and gelling agent could be eliminated in embryo culture qf coconut. However, $\mathrm{pH}$ qf the medium has to he adjusted.
\end{abstract}

\section{INTRODUCTION}

One of the types of coconut (Cocos nucifera L.) is the Makapuno coconut which is characterized by a soft enclosperm that fills the nut. Embryos of Makapuno coconuts do not germinate in situ clue to this abnormality of the enclosperm. The team of de Guzman of UPLB clemonstrated the possibility of extracting the normal Makapuno embryo and growing it in vitro to produce true-to-type, high Makapuno yielding coconut palms (de Guzman \& del Rosario, 1964; Balaga \& de Guzman, 1971a; Rosario and de Guzman, 1976).

The PCA-ARC tissue culture team further improved the technology by looking into the other media formulations to support growth and development of coconut embryos in vitro (Rillo \& Paloma, 1990). Using Murashige and Skoog (MS) and Eeuwens (Y3) mineral formulations supplemented. with activated. charcoal, germination was hastened. Altogether the incubation was shortened from 6-8 months to 4-6 months.

\section{REVIEW OF LITERATURE}

Water in tissue culture researches should be given great attention since it constitutes $95 \%$ of the nutrient medium. Tap water contains high levels of unwanted ions. Therefore, it is passed through a series of purifying filters to free the water of contaminating ions, especially cations (positively charged ions), organic contaminants and even micro-organisms. For research purposes, water that has been glass distilled is recommended, while for research the photoplasts, cells and meristems, water which has been double distilled (Pierik, 1987).

The $\mathrm{pH}$ of the nutrient medium should also be given. an important consideration for a successful in vitro growth performance of any crop. It is predicted that a $\mathrm{pH}$ in the range of 5.0-6.5 is suitable for growth. $\mathrm{pH}$ lower than 4.5 or higher than 7.0 generally stops growth and development of cultures in vitro (Pierik, 1987). Butenko (1968) reported that if the $\mathrm{pH}$ is too low the agar becomes too, sloppy; phosphate and iron salts may precipitate; Vitamin 131 (thiamine and aneurine) and pantothenic acid become less stable; and uptake of ammonium ions is retarted.

The state of the medium is also important. Based on preliminary studies on the growth and development of zygotic coconut embryos in vitro, there was longer and greatbr primary root formation in Y3 solid than in Y3 liquid, MS solid or MS liquid media. Secondary roots were already

\footnotetext{
${ }^{1}$ Philippine Coconut Authority, Albay Research Center Banao, Guinobatan Albay 4503, Philippines
} 
evident in seedlings cultured in Y3 solid medium. The average number of scale leaf formation, however, was the same in Y3 solid, Y3 liquid and MS solid. After another four weeks in culture, it was observed that there were more formation of expanded leaf and greater ramification of secondary roots in Y3 solid medium than in the other media (PCA-Annual Report, 1990). However, since sampling was not enough to really come up with conclusive statements, a follow-up study on the effect of the water source, $\mathrm{pH}$, and state of the medium was conducted.

\section{OBJECTIVES}

Generally, this study aims to determine if mass propagation cost of Makapuno using embryo culture could be reduced.

Specifically, it aims to investigate the effects of water quality, $\mathrm{pH}$ and state of the medium on growth and development of coconut embryos in vitro.

\section{MATERIALS AND METHODS}

Embryos were excised from 10-11 month-old nuts collected from Laguna Tall palms. They were cultured following the protocol established by Rillo and Paloma (1992). The treatments were assigned completely at random in a three-factor experiment using single-factor experimental design. The following factors were considered:

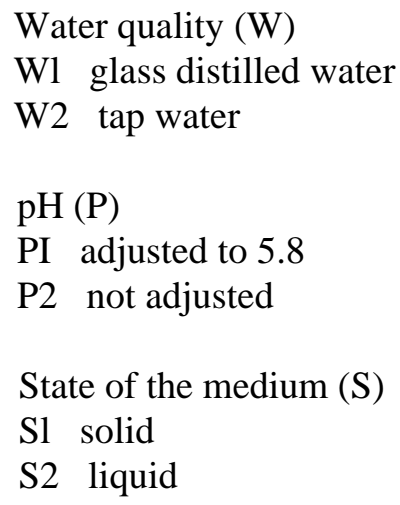

Treatments were replicated 4 times with 20 samples per replicate.

Germination of embryo, shoot and root lengths were recorded after one month in culture. Plant height and further root elongation were regularly measured, 2, 3, and 4 months after initial culture.

Data were analyzed using ANOVA. Means were compared using the Duncan's Multiple Range Test (DMKr).

\section{DISCUSSION OF RESULTS}

Statistical analysis showed that quality of water and $\mathrm{pH}$ of the media affected root length but not percent germination and shoot length of 10 to 11 month-old Laguna embryos (Fig. 1 a \& b) after one month in culture. Longer roots and shoot lengths were observed in embryos germinated in Y3 liquid media which used glass distilled water or $\mathrm{pH}$ adjusted to 5.8 (Table 1). However, their interaction effect was not significant. 
After a 2-month incubation, the increase in plant height was significantly affected by state and $\mathrm{pH}$ of the medium but not by the quality of water. Although not significantly different, the increment in plant height was higher in tap water. Higher increment in plant height was observed in Y3 solid than in liquid medium. Likewise, adjustment to ph to 5.8 resulted to taller seedlings. The increment in root length of the seedlings was not significantly affected by any of the variables tested (Table 2).

Incubation of the seedlings in their respective medium for three to four months showed that only $\mathrm{pH}$ significantly affected plant height (Table 2, Fig. 2). The effect of $\mathrm{pH}$ in terms of increment in root length was observed only after 3 months. This effect, however, became negligible after the fourth month in culture. No interaction effect among the three factors was detected.

Table 1. Mean pereent germination, shoot and root length after one month incubation in Y3 liquid germination medium

\begin{tabular}{|l|c|c|c|}
\hline \multicolumn{1}{|c|}{ VARIABLES } & \% Germination & Shoot length & Root length (mm) \\
\hline Glass distilled & & & \\
water (W 1) & $85.3 \mathrm{a}$ & $1.5 \mathrm{a}$ & $7.4 \mathrm{a}$ \\
Tap water (W2) & $86.9 \mathrm{a}$ & $1.4 \mathrm{a}$ & $6.2 \mathrm{~b}$ \\
+ $\mathrm{pH}$ (P 1) & $88.1 \mathrm{a}$ & $1.8 \mathrm{a}$ & $7.6 \mathrm{a}$ \\
- $\mathrm{pH}$ (P2) & $84.1 \mathrm{a}$ & $1.2 \mathrm{a}$ & $5.9 \mathrm{~b}$ \\
\hline
\end{tabular}

* Means with the same letter in the same block are not significantly different at $5 \%$ level of DMRT

Table 2. Mean increment in plant height and root length after two to four months incubation *

\begin{tabular}{|c|c|c|c|c|c|c|}
\hline \multirow{2}{*}{ Variables } & \multicolumn{3}{|c|}{ Increment in Plant Height $(\mathrm{mm})$} & \multicolumn{3}{|c|}{ Increment in root Length $(\mathrm{mm})$} \\
\hline & $2 \mathrm{mo}$ & $3 \mathrm{mo}$ & $4 \mathrm{mo}$ & $2 \mathrm{mo}$ & $3 \mathrm{mo}$ & $4 \mathrm{mo}$ \\
\hline Glass distilled & & & & & & \\
\hline water (W1) & $9.7 \mathrm{a}$ & $14.0 \mathrm{a}$ & $34.3 \mathrm{a}$ & $12.6 \mathrm{a}$ & $8.0 \mathrm{a}$ & $5.8 \mathrm{a}$ \\
\hline Tapwater(W2) & $11.4 \mathrm{a}$ & $16.2 \mathrm{a}$ & $38.0 \mathrm{a}$ & $13.2 \mathrm{a}$ & $7.2 \mathrm{a}$ & $6.0 \mathrm{a}$ \\
\hline solid medium(S1) & $11.4 \mathrm{a}$ & $15.2 \mathrm{a}$ & $37.1 \mathrm{a}$ & $13.7 \mathrm{a}$ & $7.6 \mathrm{a}$ & $5.0 \mathrm{a}$ \\
\hline liquid medium (S2) & $8.7 \mathrm{~b}$ & $15.0 \mathrm{a}$ & $35.2 \mathrm{a}$ & $11.3 \mathrm{a}$ & $7.5 \mathrm{a}$ & $6.8 \mathrm{a}$ \\
\hline$+\mathrm{pH}(\mathrm{P} 1)$ & $12.1 \mathrm{a}$ & $16.9 \mathrm{a}$ & $40.3 \mathrm{a}$ & $14.5 \mathrm{a}$ & $8.7 \mathrm{a}$ & $6.4 \mathrm{a}$ \\
\hline$-\mathrm{pH}(\mathrm{P} 2)$ & $8.9 b$ & $13.4 \mathrm{~b}$ & $32.0 \mathrm{~b}$ & $11.3 \mathrm{a}$ & $6.4 \mathrm{~b}$ & \\
\hline
\end{tabular}

* Means with the same letter in the same block are not significantly different at $5 \%$ level of DMRT

Chemical analysis of the tap water collected from Albay Research Centre showed that it contained $4.76 \mathrm{ppm}$ potassium, $26.0 \mathrm{ppm}$ calcium, $10.8 \mathrm{ppm}$ magnesium, $14.4 \mathrm{ppm}$ sodium, $2.0 \mathrm{ppm}$ chloride, $2.4 \mathrm{ppm}$ sulfur and nil amount of nitrogen, phosphorus and boron. From the results, it is safe to assume that the ions present in the tap water did not significantly affect growth and development of coconut embryos. The $\mathrm{pH}$ of the $\mathrm{Y} 3$ media which used glass distilled water and tap water ranged from 4.8-5.0 and 6.2-6.4, respectively (Table 3). Skirvin et al (1986) reported that $\mathrm{pH}$ changes after autoclaving. If the starting $\mathrm{pH}$ is in the range of 5.0-7.0, it generally lowers by $0.3-0.5$ unit. The $\mathrm{pH}$ range of 5.0-6.5 is predicted suitable for growth with an optimum at about 6.0 (Pierik, 1987). Hence, assuming a reduction of 0.3-0.5 units in $\mathrm{pH}$ due to autoclaving, the $\mathrm{pH}$ of the autoclaved culture media which used tap water with or without $\mathrm{pH}$ adjustment was within the predicted suitable range for growth (Table 3 ). The $\mathrm{pH}$ after autoclaving of culture media which used distilled water could be below the $\mathrm{pH}$ range for growth if $\mathrm{pH}$ was not adjusted prior to autoclaving. 
Table 3. pH range of the culture medium before and after autoclaving

\begin{tabular}{|l|c|c|c|}
\hline \multirow{2}{*}{} & \multicolumn{2}{|c|}{$\mathrm{pH}$ OF THE CULTURE MEDIUM } \\
\cline { 2 - 3 } & \multicolumn{2}{|c|}{ Before Autoclaving } & \multirow{2}{*}{ After Autoclaving $^{\mathrm{a}}$} \\
\cline { 2 - 3 } & Before Adjustment & After Adjustment & 5.3 \\
W1P1S1 & $4.9-5.0$ & 5.8 & $4.4-4.5$ \\
W1P2S1 & $4.9-5.0$ & - & 5.3 \\
W1IP1S2 & $4.8-5.0$ & 5.8 & $4.3-4.5$ \\
W1P2S2 & $4.8-5.0$ & - & 5.3 \\
W2P1S1 & $6.2-6.4$ & 5.8 & $5.7-5.9$ \\
W2P2S1 & $6.2-6.4$ & - & 5.3 \\
W2P1S2 & $6.2-6.4$ & 5.8 & $5.7-5.9$ \\
W2P2S2 & $6.2-6.4$ & - & \\
\hline
\end{tabular}

a - $\mathrm{Ph}$ range assuming a reduction in $\mathrm{pH}$ by 0.5 units.

The cost of producing an in vitro-cultured Makapuno in a solid medium with glass distilled water and $\mathrm{pH}$ adjustment, as previously applied for coconut embryo culture, was found expensive (P150.35). Comparing the cost of the previous method (W1P1S1) with the other treatments suitable for embryo culture, the amount saved was P3.61, P15.23, and as much as P18.84 with W1P1S2, W2P 1S1 and W2P1S2, respectively (Table 4).

Total volume of medium prepared per embryo:

$\begin{array}{ll}\text { Initial } & 15 \mathrm{ml} \\ 1^{\text {st }} \text { subculture } & 20 \mathrm{ml} \\ 2^{\text {nd }} \text { subculture } & 50 \mathrm{ml} \\ 3^{\text {rd }} \text { subculture } & 80 \mathrm{ml} \\ 4^{\text {th }} \text { subculture } & 80 \mathrm{ml}\end{array}$

TOTAL $245 \mathrm{ml}-250 \mathrm{ml}$

2/ Estimate was based on the salary of a Lab. aide directly involved.

3/ See Table 5 for the computations

4/ Water source:

a. Triple distilled water (BYCON)

P 35.85

$\mathrm{x} 250 \mathrm{ml}=\mathrm{p} 8.96$ per $250 \mathrm{ml}$ medium

$1000 \mathrm{ml}$

5/ Factor used on finding that $70 \%$ of total embryos are lost at different stages of culture.

6/ Computed by subtracting the cost of other treatments from the cost incurred using the previous method (W1P1S1). 
Table 4. Estimated cost of production per embryo from initial to rinal subeulture ${ }^{\mathrm{l}}$

\begin{tabular}{|l|r|r|r|r|r|r|r|r|}
\hline \multicolumn{1}{|c|}{ ITEM } & W1P1S1 & W1P1S2 & W2P1S1 & W2P1S2 & W1P2S1 & W1P2S2 & W2P2S1 & W2P2S2 \\
\hline Salary 2l & 40.00 & 40.00 & 40.00 & 40.00 & 40.00 & 40.00 & 40.00 & 40.00 \\
Cost of embry0 & 6.00 & 6.00 & 6.00 & 6.00 & 6.00 & 6.00 & 6.00 & 6.00 \\
Chemical3/ $^{\text {Water source4/ }}$ & 5.31 & 3.19 & 0.001 & 0.001 & 8.96 & 8.96 & 0.001 & 0.001 \\
pH adjustment & 8.96 & 8.96 & 1.17 & 1.17 & - & - & - & - \\
Light \& water & 1.17 & 1.17 & 12.00 & 12.00 & 12.00 & 12.00 & 12.00 & 12.00 \\
Misc Lab supplies & 12.00 & 12.00 & 15.00 & 15.00 & 15.00 & 15.00 & 15.00 & 15.00 \\
TOTAL & 15.00 & 15.00 & 5.31 & 3.19 & 5.31 & 3.19 & 5.31 & 3.19 \\
& 88.44 & 86.32 & 79.48 & 77.36 & 87.27 & 85.15 & 78.31 & 76.19 \\
\hline Cost/embryo & $1.755 /$ & $\times 1.7$ & $\times 1.7$ & $\times 1.7$ & $\times 1.7$ & $\times 1.7$ & $\times 1.7$ & $\times 1.7$ \\
Savings6/ & 150.35 & 146.74 & 13.12 & 131.51 & 148.36 & 144.76 & 133.12 & 129.52 \\
\hline
\end{tabular}

${ }^{1 /}$ These estimates did not consider the infrastructure, equipment, glasswares, other supplies and salaries of other people involved in the supervision of the work.

Table 5. Cost of chemical per embryo (in Pesos) depending on the state of the medium

\begin{tabular}{|c|c|c|c|c|c|}
\hline \multirow{2}{*}{ CHEMICAL } & \multirow{2}{*}{$\mathrm{G} / 250 \mathrm{ml}^{1 /}$} & \multirow{2}{*}{ UNIT COST } & \multirow{2}{*}{ Price/gram } & \multicolumn{2}{|c|}{ Total Cost } \\
\hline & & & & Solid & Liquid \\
\hline $\mathrm{Cacl}_{2}, 2 \mathrm{H}_{2} \mathrm{O}$ & 0.007 & $4899 / \mathrm{k}$ & 0.899 & 0.07 & 0.07 \\
\hline $\mathrm{MgSO}_{4}, 7 \mathrm{H}_{2}$ & 0.062 & $631 / 500 \mathrm{~g}$ & 1.262 & 0.08 & 0.08 \\
\hline $\mathrm{NaH}_{2} \mathrm{PO}_{4} \mathrm{H}_{2}$ & 0.078 & $892 / 500 \mathrm{~g}$ & 1.784 & 0.14 & 0.14 \\
\hline $\mathrm{KNO}_{3}$ & 0.505 & $625 / 500 \mathrm{~g}$ & 1.250 & 0.6 & 0.63 \\
\hline $\mathrm{KCl}$ & 0.373 & $703 / \mathrm{k}$ & 0.703 & 0.26 & 0.26 \\
\hline $\mathrm{NH}_{4} \mathrm{Cl}_{2}$ & 0.134 & $892 / \mathrm{k}$ & 0.892 & 0.12 & 0.12 \\
\hline $\mathrm{MnSO}_{4}, 7 \mathrm{H}_{2} \mathrm{O}$ & 0.002 & $582 / 100 \mathrm{~g}$ & 5.820 & 0.012 & 0.012 \\
\hline $\mathrm{ZnSO}_{4}, 7 \mathrm{H}_{2} \mathrm{O}$ & 0.002 & $571 / 500 \mathrm{~g}$ & 1.142 & 0.002 & 0.002 \\
\hline $\mathrm{H}_{3} \mathrm{~B}_{3}$ & 0.001 & $495 / 500 \mathrm{~g}$ & 0.990 & 0.001 & 0.001 \\
\hline KI & 0.002 & $1468 / 250 \mathrm{~g}$ & 5.872 & 0.012 & 0.012 \\
\hline $\mathrm{CuSo}_{4}, 5 \mathrm{H}_{2} \mathrm{O}$ & 0.00006 & $467 / 250 \mathrm{~g}$ & 1.868 & 0.0001 & 0.0001 \\
\hline $\mathrm{Na}_{2} \mathrm{MoO}_{4}, 2 \mathrm{H}_{2} \mathrm{O}$ & 0.00006 & $1513 / 100 \mathrm{~g}$ & 15.13 & 0.001 & 0.001 \\
\hline $\mathrm{CoCl}_{2}, 6 \mathrm{H}_{2} \mathrm{O}$ & 0.00006 & $1532 / 100 \mathrm{~g}$ & 15.32 & 0.001 & 0.001 \\
\hline $\mathrm{NiCl}_{2}, 6 \mathrm{H}_{2} \mathrm{O}$ & 0.000006 & $1345 / 250 \mathrm{~g}$ & 5.380 & 0.0003 & 0.00003 \\
\hline FeNaEDTA & 0.009 & $2160 / 250 \mathrm{~g}$ & 8.640 & 0.08 & 0.08 \\
\hline Myo-inositol & 0.025 & $1066 / 100 \mathrm{~g}$ & 10.660 & 0.27 & 0.27 \\
\hline Thiamine $\mathrm{HCl}$ & 0.000125 & $756 / 250 \mathrm{~g}$ & 3.024 & 0.0004 & 0.0004 \\
\hline Nictonic acid & 0.0000125 & $1003 / 100 \mathrm{~g}$ & 10.03 & 0.0001 & 0.0001 \\
\hline Pyridoxine $\mathrm{HCl}$ & 0.0000125 & $1205 / 10 \mathrm{~g}$ & 120.5 & 0.002 & 0.002 \\
\hline Ca D-pantothenate & 0.0000125 & $220.5 / 5 \mathrm{~g}$ & 44.1 & 0.001 & 0.001 \\
\hline d-Biotin & 0.0000125 & $1177 / 100 \mathrm{~g}$ & 11.77 & 0.0002 & 0.0002 \\
\hline Act. Charcoal & 0.625 & $2080 / \mathrm{k}$ & 2.08 & 1.3 & 1.3 \\
\hline Agar-agar Japan ${ }^{2 /}$ & 1.38 & $700 / 500 \mathrm{~g}$ & 1.54 & 2.12 & - \\
\hline $\mathrm{NAA}^{3 /}$ & 0.002 & $200 / 500 \mathrm{~g}$ & 0.04 & 0.001 & 0.001 \\
\hline Sugar & 11.25 & $19 / \mathrm{k}$ & 0.019 & 0.21 & 0.21 \\
\hline TOTAL & & & & 5.31 & 3.19 \\
\hline
\end{tabular}


1/ Total volume of medium prepared for embryo:

$\begin{array}{ll}\text { Initial } & 15 \mathrm{ml} \\ 1^{\text {st }} \text { subc } & 20 \mathrm{ml} \\ 2^{\text {nd }} \text { subc } & 50 \mathrm{ml} \\ 3^{\text {rd }} \text { subc } & 80 \mathrm{ml} \\ 4^{\text {th }} \text { subc } & \underline{80 \mathrm{ml}}\end{array}$

$245 \mathrm{ml}-250 \mathrm{ml}$

2/ Solid medium $(6 \mathrm{~g} / \mathrm{l}): 1^{\text {st }}-4^{\text {th }} \mathrm{subc}=\mathrm{subc}=230 \mathrm{ml}$

3/ NAA $10 \mathrm{mg} / \mathrm{l}-0,01 \mathrm{~g} / \mathrm{l}$
$\frac{\mathrm{x} \quad 160 \mathrm{ml}}{0.002 \mathrm{~g}}$$\left(3^{\text {rd }} \& 4^{\text {th }} \mathrm{subc}\right)$

\section{CONCLUSION}

Percent germination of 10 to 11 month-old Laguna embryos cultured in Y3 liquid medium was, not affected by either water quality or $\mathrm{pH}$ adjustment. However, further culture of the coconut embryos showed that $\mathrm{pH}$ adjustment is a critical factor. The quality of water and state of the medium are not very important factors. The culture medium for coconut embryos could, therefore, use tap water, without agar but with $\mathrm{pH}$ adjustment. The elimination of agar and the use of ordinary tap water will greatly reduce the production cost of in-vitro cultured Makapuno coconuts.

\section{RECOMMENDATIONSTOLICY IMPLICATIONS}

The results of this study influenced partly the policy of Philippine Coconut Authority to reduce the selling price of in vitro grown Makapuno seedlings from P 500.00 to P300.00 per piece, thereby, allowing more small coconut fariners to afford this high value coconut type. Sociologically and economically, the availment of this type of coconut will benefit the farmers in the form of being able to sell high value coconuts helping them in the short to medium term. 


\section{REFERENCES}

BALAGA, H. M. \& E.V. de GUZMAN. 1971a. The growth and development of coconut 'Makapuno' embryos in vitro. II. Increased root incidence and growth and response to media composition and to sequential culture from liquid to solid medium. Phil. Agric. 53(10): $551-565$.

BUTENKO, R.G. 1968. Plant tissue culture and plant morphogenesis. In: Pierik, R. L. M. 1987. In vitro culture of higher plants. Martinus Nijhoff Publishers, Dordrecht, Netherlands, 344 pp.

GUZMAN, E.V. de \& D.A, del ROSARIO. 1964. The growth and development of Cocos Nucifera L. 'Makapuno' embryos in vitro. Phil. Agric. 48(2-3): 82-94.

PCA ANNUAL REPORT. 1990. Performance of Catigan embryos in MS solid, MS liquid, Y3 solid and Y3 liquid media. In: Growth and development of zygotic coconut embryos in vitro-Improvement of root growth. $146 \mathrm{pp}$.

PIERIK, R.L.M. 1987. In vitro culture of higher plants. Martinus Nijhoff Publishers, Dordrecht, Netherlands. 344 pp.

RILLO, E. P. \& M. B. F. PALOMA. 1990. Comparison of three media formulations for in vitro culture of coconut embryos. Oleagineux 45 (2): 319-323

RILLO, E. P. \& M. B. F. PALOMA. 199Z. In vitro culture of Makapuno coconut embryos. Coconuts Today 9(1): 90-101

ROSARIO, A.G. del \& E.V de GUZMAN. 1976. The growth of coconut 'Makapuno' embryos in vitro as affected by mineral com position and sugar level of the medium during the liquid and solid cultures. Phil. J. Sci. 105: 215-222.

SKIRVIN, R. M., M. C. CHU, M. L. MANN, H. YOUNG, J. SULLIVAN \& T. FERMANIAN. 1986. Stability of tissue culture medium $\mathrm{pH}$ as a function of autoclaving, time and cultured plant material. Plant Cell Rep. 5:292-294.

\section{ACKNOWLEDGMENT}

The authors gratefully acknowledge the support provided by the Philippine Coconut Authority and the Deutsche Gessellschaft fur Technische Zusammenarbeit (GTZ). This work forms part of the Philippine-German Coconut Tissue Culture Project. 